reports of the Red-headed Woodpecker attacking and killing young birds and raiding nests for eggs. Most of them relate to hole-nesting species and go back as far as the 1880's and Mr. Bent writes: 'But not all Red-headed Woodpeckers are cannibals or murderers . . . and all of them have some harmless and useful feeding habits ....'"6

The behavioral patterns of our feathered friends never cease to retain the interest of a birdwatcher!

I wish to thank Mr. Herb Copland for providing references from A.G. Lawrence.

' BANCROFT, J. 1982. Trees for cavity- dwellers. Blue Jay 40(3):166-167.

2 BANCROFT, J. 1983. Red-headed Woodpecker. Blue Jay 41(3):164-165.

${ }^{3}$ GODFREY, W.E. 1966. The Birds of Canada Nat. Mus. Canada Bull. 203

${ }^{4}$ HARRISON, H.H. 1975. a Field Guide to Birds' Nests in the United States east of the Mississippi River. Houghton Mifflin, Boston. $257 \mathrm{pp}$.

${ }^{5}$ LAWRENCE, A.G. 1928. The Red-head to Blame? Chickadee Notes No. 377 , Winnipeg Free Press, 14 June, 1928.

${ }^{\circ}$ LAWRENCE, A.G. 1950. Reports on Cuckoos and Red-headed Woodpeckers, Chickadee Notes No. 1529, Winnipeg Free Press, 8 Sept. 1950.

\title{
BIRDS NESTING WITH QU'APPELLE BANK SWALLOWS
}

DALE G. HJERTAAS and PAULE HJERTAAS, 919 Cook Crescent, Regina, Saskatchewan. S4X 2L9

In 1980 and 1981 we studied the nesting ecology of Bank Swallows at 60 colonies in a 6,129 hectare area around Katepwa Lake in the Qu'Appelle Valley.' During the course of this study we noted five other species of birds nesting in the Bank Swallow tunnels.

Given the House Wren's propensity for stuffing twigs into any available cavity, perhaps the greatest surprise is that we found only two pairs nesting in Bank Swallow burrows. However, only 12 of the 60 colonies had any wooded vegetation at the bank top. The House Wrens nested in 2 of these 12 potential sites. Both nests were believed to be successful; young were observed fledging at one nest.
Just outside the Qu'Appelle Valley south of Lebret lies a sandy grassland which is used for pasture and exploited for gravel. We observed five Mountain Bluebird nest attempts in Bank Swallow tunnels at these gravel pits. Four of the nests were successful. One pair raised two broods in the same tunnel, another initiated its nest after Bank Swallows had fledged on 5 July.

House Sparrows not on!y nested in, but apparently were year rourid residents at certain colonies. Almost all nestings by House Sparrows were at two colonies in the village of Lebret and one on a hillside near the outlet of Katepwa Lake. This latter site, which was at least $0.25 \mathrm{mi}$. 
from the nearest buildings, was used by eight pairs of House Sparrows in 1980. House Sparrows were seen on each subsequent visit to the colony including an observation of 21 on 18 February 1984. We believe the Bank Swallow tunnels at this colony provide year-round shelter for House Sparrows.

The three colonies used by House Sparrows were characterized by fineparticled soils which eroded slowly. The Bank Swallow tunnels last for several years and may allow House Sparrows to establish a nesting tradition. Most Bank Swallow colonies in the area were in sandy soils where tunnels usually collapsed within one or two years.

Three Belted Kingfisher nests were observed in Bank Swallow colonies. The history of the nest at Katepwa Lake is not known. The other two nests which were on the bank of, and adjacent to, Moose Jaw Creek in Buffalo Pound Provincial Park, were in marked Bank Swallow tunnels from the previous year. While the Kingfisher had increased the diameter and depth of the tunnel, use of an old Bank Swallow tunnel must have saved significant effort in excavation.

Our fifth observed species, a Brewer's Blackbird, nested in a niche created by a bit of erosion at a swallow tunnel mouth. Although the nest was nat really in the burrow, the Bank Swallow tunnel was the essential feature creating the nest site. This nest was pulled off its ledge by a passerby.

Each of these species seemed to interact little with the Bank Swallows. House Sparrows occupied tunnels which may have otherwise been reused by Bank Swallows. This may force some Bank Swallows to excavate new tunnels or even move to other colonies, but this interaction was not studied. The House Wren may have been an asset to the colony due to its vigilant defence of its territory against potential predators. On 13 June 1980 we watched a House Wren chase a Least Chipmunk and a Thirteenlined Ground Squirrel off the nest bank. This was an amazing sight as the House Wren is tiny, even beside the chipmunk. Nonetheless, both departed rapidly without argument. Interestingly, the Bank Swallows themselves had totally ignored the presence of these potential nest predators on the nest bank.

Some of you may have expected some mention of Rough-winged Swallows. No Rough-winged Swallows nested anywhere in our 6,129 hectare study area in 1980 or 1981 . While we have found Rough-winged Swallow nests further west in the Qu'Appelle near Craven and in Buffalo Pound Provincial Park, these were solitary nests.

1 HJERTAAS, D.G. 1984. Colony site selection in Bank Swallows. MSc. Thesis, University of Saskatchewan, Saskatoon.

\section{SASKATCHEWAN CHRISTMAS BIRD AND MAMMAL COUNTS}

Count period is from Saturday, 15 December 1984 to Wednesday, 2 January, inclusive. Count area should be a circle $24 \mathrm{~km}$ (15 miles) in diameter. Count forms will be sent to compilers who submitted counts for 1983. Anyone else who wishes to send in a count please write for forms to Mary I. Houston, 863 University Drive, Saskatoon, Saskatchewan. S7N 0J8

Reports of counts should be sent to Mary Houston as soon as possible after they are taken. To be included in the report in the March 1985 Blue Jay they must reach Mary by 10 January at the very latest. 